\title{
Gap Between Current and Ideal Immediate Normal Postpartum Nursing Care at Woman's Health University Hospital, Assiut.
}

\author{
Mervat M. Hassan, Ali M. El-Seman, Nabila Taha \& Nadia A. Mohammed. \\ Assistant lecturer obstetrics \& Gynecological nursing, faculty of Nursing South Valley University Egypt . \\ Professor of Obstetrics \& Gynecology, Faculty of Medicine Assiut University Egypt . \\ Assistant Professor Obstetrics \& Gynecological Nursing, Faculty of Nursing Assiut University Egypt . \\ Assistant Professor Obstetrics \& Gynecological Nursing, Faculty of Nursing South University Egypt.
}

\begin{abstract}
Improving the quality of obstetric care is an urgent priority in developing countries where maternal mortality remains high. Optimal obstetric care is the key requirement in reducing maternal mortality. The Aim of this study is to identifying the gap between the current and ideal Immediate normal postpartum nursing care at Woman's Health University Hospital, Assiut. Descreptive observational Design was used. Convenient Sample of 500 women were included. Data collected from June 2013 to January 2014, an interview questionnaire and clinical audit chart were used. The Results revealed that mean age of subjects was $27.83 \pm 4.85$ years, multiparae constitutes more than half of subjects . Hygienic \& nutritional advices were not done by nurses. Breast beefing advices were provided to around one quarter of subjects. Check for uterine contractions was provided by the nurse for nearly half of subjects. Immediate newborn care was provided by nurses in different high percentages, while monitor baby breathing not done by nurses. It is Concluded that, a gaps were identified between current and ideal immediate normal postpartum nursing care. Hygienic \& nutritional advices not provided by nurses. All items of immediate post-partum care except check for uterine contractions not provided by the nurses. Immediate newborn care was the most item of care provided by the nurse. Reaudit is Recommended to improve quality care.
\end{abstract}

\section{Key Words:- Immediate Post Partum Period, Audit \& Ideal Care.}

\section{Introduction}

Primary responsibilities of nurses in postpartum settings are to assess postpartum patients, provide care and teaching, and if necessary, report any significant findings. Postpartum nurses are essentially detectives searching for findings that might lead to negative outcomes for patients if left unattended (Moldenhauer, 2013) .Postpartum period is a very special phase in the life of women and newborn and forms a part of the normal continuum of reproductive cycle. Immediate post-partum period referred to the first 24hours after birth. (Ricci \& Kyle, 2009). Nurses need to be aware of the normal physiological and psychological changes that take place in clients' bodies and minds in order to provide comprehensive care during this period. In addition to client and family teaching, one of the most significant responsibilities of the postpartum nurse is to recognize potential medical complications after delivery (Bethany et al., 2010). The provision of midwifery care to women following the birth of their baby aims to encompass aspects of observing and monitoring the health of the new mother and her baby as well as offering support and guidance in breast feeding and parenting skills. (Swell, 2007). As a result there have been increasing numbers of research studies that challenge the traditional pattern of postpartum care and its overall provision and value (Wary et al., 2008 ).

The period soon after childbirth process substantial health risks for both mother and newborn infant. Yet the postpartum period receives less attention from health care providers than pregnancy and childbirth. Models of postpartum care have changed little since first developed acentury ago. The World Health Organization (WHO) is in the process of revising and updating its guidance on immediate postpartum care delivered by skilled providers. The purposes of revision are to encourage and support broader provision of care that promotes health as well as maintains vigilance against dangerous complications. (WHO, 2010). To ensure that a good quality of care is provided, one technique that has been developed for this purpose is clinical audit. (Graham et al., 2012). Clinical audit is a continuous process about improving practice and providing a better service. Practitioners are expected to measure and demonstrate the effectiveness of the care they provide and one way of assessing practice by clinical audit (Kitson et al., 2012).

\section{Significance of the study}

More than $70 \%$ of maternal deaths occur in the 
postpartum period, especially in developing countries , $77 \%$ of these deaths occur during or shortly after childbirth (within 24 hours). (John \& Sons, 2007). Studies have found that at least $88-98 \%$ of maternal deaths can be prevented if good quality emergency obstetric care is available (NHS Executive, 2010). Postpartum care remains a vital part of the childbearing process that the midwife has to provide for the mother and baby immediately following birth (WHO, 2006).

\section{Research Question}

Is there a gap between the current \& ideal immediate normal post-partum nursing care at Woman's Health University Hospital, Assiut.

\section{Aim of the work}

Identifying the gap between the current and ideal immediate normal postpartum nursing care at Woman's Health University Hospital, Assiut.

\section{Subject \& method}

\section{Research design}

Descriptive observational design was used for this study.

\section{Setting}

This study was conducted at the Women's Health University Hospital, Assuit, which provides free services for rural and urban areas. Annual delivery rate reach to 25000 approxmaitely.

\section{Subjects}

Convenient sample of normal vaginal delivered women. According to sample equation 500 women included in this study.

\section{Inclusion criteria}

Normal vaginal delivery.

Tools of data collection

The following tools were used.

\section{1-Interviewing questionnaire}

Developed by the investigator and included: socio demographic data, menstrual history, past obstetrical history, medical history, family planning history, \& present history.

\section{2-Clinical Audit chart (observational check list)}

This tool designed by WHO (2003) according to guidelines standard of essential obstetric care for postpartum women and baby If consists of different tasks that are to be performed immediately after delivery, checked by done or not done. Modified by adding four colomns, done by high qualified nurse, staff nurse, student's nurse, others .

Include:- the ideal care \& advices should provide to mothers, the ideal care should provide to newborn, advices and counseling should provide to mothers regards postpartum care and hygiene, breastfeeding, nutrition, and prevention of micronutrient deficiencies.

Administrative approval

The necessary official permission was obtained from the Dean of Faculty of Nursing, Assiut University to proceed with the study and from the chairman of Womam's Health University Hospital, Assiut to proceed with the study.

\section{Ethical Considerations}

Research proposal approved from ethical committee in the faculty of nursing.There is no risk for study subjects during application of the study. An oral consent were obtained from women and nurses after explaining the nature and purpose of the study.Confidentiality and anonymity were assured.

\section{Pilot study}

A pilot study carried on $10 \%$ of the total subjects (50 woman) to test the validty and consistency of the tool and to detect any modifications needed, those subjects were included in the study. Omit high qualified nurse from care providers in clinical audit chart were recommended after application of pilot study

\section{Filed work}

The investigator interviewed the women to fulfill the questionnaire, observe the nursing staff who provide the immeadiate postpartum nursing care for the women \& newborn and recording in the clinical audit chart. All nurses working in labor room were diploma nurse.They were nine nurses, only two nurses in every shift, two nurses off and one nurse responsible for administrative work. Data collection started on June 2013 and ended by January 2014. Data were collected three days a week during morning shift. Four to six women were delivered during this period and included in the study.

\section{Statestical analysis}

The collected data were tabulated and entry in excel sheets. Data analysed by using SPSS program version 19. Data were presented using descriptive statistics in the form of frequencies and percentages for qualitative variables, and means and standard deviations for quantitative variables. 


\section{Results}

Table (1):Distribution of the study subjects by their socio-emographic characteristics.

\begin{tabular}{|c|c|c|}
\hline Demographic characteristics & No. $(n=500)$ & $\%$ \\
\hline \multicolumn{3}{|l|}{ Age } \\
\hline$<25$ years & 127 & 25.4 \\
\hline $25-<30$ years & 194 & 38.8 \\
\hline $30-<35$ & 123 & 24.6 \\
\hline$\geq 35$ years & 56 & 11.2 \\
\hline Mean \pm SD (Range) & \multicolumn{2}{|c|}{$27.83 \pm 4.85(19-45)$} \\
\hline \multicolumn{3}{|l|}{ Level of education: } \\
\hline Illiterate & 9 & 1.8 \\
\hline Read \& write & 12 & 2.4 \\
\hline Primary & 77 & 15.4 \\
\hline Preparatory & 105 & 21.0 \\
\hline Secondary & 226 & 45.2 \\
\hline University & 71 & 14.2 \\
\hline \multicolumn{3}{|l|}{ Occupation } \\
\hline Housewife & 481 & 96.2 \\
\hline Employed & 19 & 3.8 \\
\hline \multicolumn{3}{|l|}{ Residence } \\
\hline Rural & 381 & 76.2 \\
\hline Urban & 119 & 23.8 \\
\hline
\end{tabular}

Table (2): Distribution of the study subjects by their Obstetrical history.

\begin{tabular}{|c|c|c|}
\hline Obstetrical history & No. $(n=500)$ & $\%$ \\
\hline \multicolumn{3}{|l|}{ Number of gravidity } \\
\hline 1 & 65 & 13.0 \\
\hline $2-4$ & 358 & 71.6 \\
\hline$\geq 5$ & 77 & 15.4 \\
\hline \multicolumn{3}{|l|}{ Number of parity } \\
\hline 1 & 91 & 18.2 \\
\hline $2-4$ & 344 & 68.8 \\
\hline$\geq 5$ & 65 & 13 \\
\hline \multicolumn{3}{|l|}{ Number of abortions } \\
\hline 0 & 377 & 75.4 \\
\hline 1 & 87 & 17.4 \\
\hline 2 or more & 36 & 7.2 \\
\hline \multicolumn{3}{|l|}{ Number of stillbirths } \\
\hline 0 & 493 & 98.6 \\
\hline 1 & 7 & 1.4 \\
\hline \multicolumn{3}{|l|}{ Number of neonatal deaths } \\
\hline 0 & 495 & 99.0 \\
\hline 1 & 3 & 0.6 \\
\hline 2 or more & 2 & 0.4 \\
\hline \multicolumn{3}{|l|}{ Number of living children } \\
\hline One & 95 & 19.0 \\
\hline $2-3$ & 292 & 58.4 \\
\hline$>3$ & 113 & 22.6 \\
\hline
\end{tabular}




\section{Type of delivery}

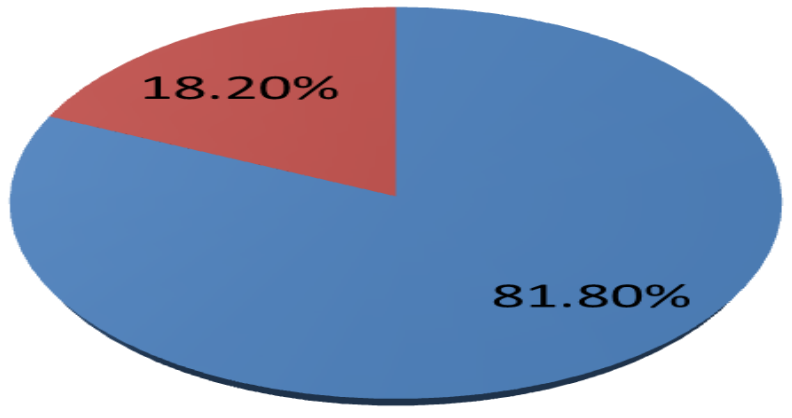

SVD without episiotomy

SVD with episiotomy

Figure (1): Distribution of the study subjects by their type of delivery

Table (3): Distribution of the study subjects by immediate postpartum nursing care \& care providers.

\begin{tabular}{|l|c|c|c|c|c|c|c|c|}
\hline \multicolumn{1}{|c|}{ Items of care } & $\begin{array}{c}\text { Done by staff } \\
\text { nurse }\end{array}$ & \multicolumn{2}{c|}{$\begin{array}{c}\text { Done by } \\
\text { student nurse }\end{array}$} & \multicolumn{2}{c|}{ Done by others } & \multicolumn{2}{c|}{ Not done } \\
\cline { 2 - 10 } & No. & $\mathbf{\%}$ & No. & $\mathbf{\%}$ & No. & \% & No. & $\%$ \\
\hline $\begin{array}{l}\text { Check for completeness of placenta and } \\
\text { membranes }\end{array}$ & 14 & 2.8 & 14 & 2.8 & 347 & 69.4 & 125 & 25.0 \\
\hline $\begin{array}{l}\text { Assess general maternal well-being (blood } \\
\text { pressure, body temperature, puls }\end{array}$ & 0 & 0.0 & 86 & 17.2 & 3 & 0.6 & 411 & 82.2 \\
\hline $\begin{array}{l}\text { Identify and respond to/refer immediate } \\
\text { postpartum problems such as excessive } \\
\text { bleeding (i.e., a pad soaked in less than one } \\
\text { hour), fever, elevated blood pressure }\end{array}$ & 0 & 0.0 & 4 & 0.8 & 3 & 0.6 & 493 & 98.6 \\
\hline Check for pallor (conjunctiva and palms) & 0 & 0.0 & 19 & 3.8 & 6 & 1.2 & 475 & 95.0 \\
\hline $\begin{array}{l}\text { Check perineum for tears, inflammation, } \\
\text { discharge }\end{array}$ & 52 & 10.4 & 31 & 6.2 & 309 & 61.8 & 108 & 21.6 \\
\hline $\begin{array}{l}\text { Check for uterine contraction and fundal height. } \\
\text { Feel if uterus is hard and round }\end{array}$ & 215 & 43 & 44 & 8.8 & 210 & 42.0 & 31 & 6.2 \\
\hline Encourage mother to empty bladder & 0 & 0.0 & 0 & 0.0 & 0 & 0.0 & 500 & 100.0 \\
\hline Encourage mother to eat and drink & 0 & 0.0 & 40 & 8.0 & 383 & 76.6 & 77 & 15.4 \\
\hline $\begin{array}{l}\text { Initiate early (within one hour) and frequent, } \\
\text { exclusive breastfeeding and assist the mother to } \\
\text { adopt correct breastfeeding practices }\end{array}$ & 14 & 2.8 & 83 & 16.6 & 292 & 58.4 & 111 & 22.2 \\
\hline $\begin{array}{l}\text { Advise on maternal/ newborn danger signs and } \\
\text { where to go for help }\end{array}$ & 0 & 0.0 & 30 & 6.0 & 0 & 0.0 & 470 & 94.0 \\
\hline $\begin{array}{l}\text { Advise on when to return for next postpartum } \\
\text { check-up }\end{array}$ & 0 & 0.0 & 0 & 0.0 & 0 & 0.0 & 500 & 100.0 \\
\hline
\end{tabular}

Others mean obstetrician or nurse's aids 


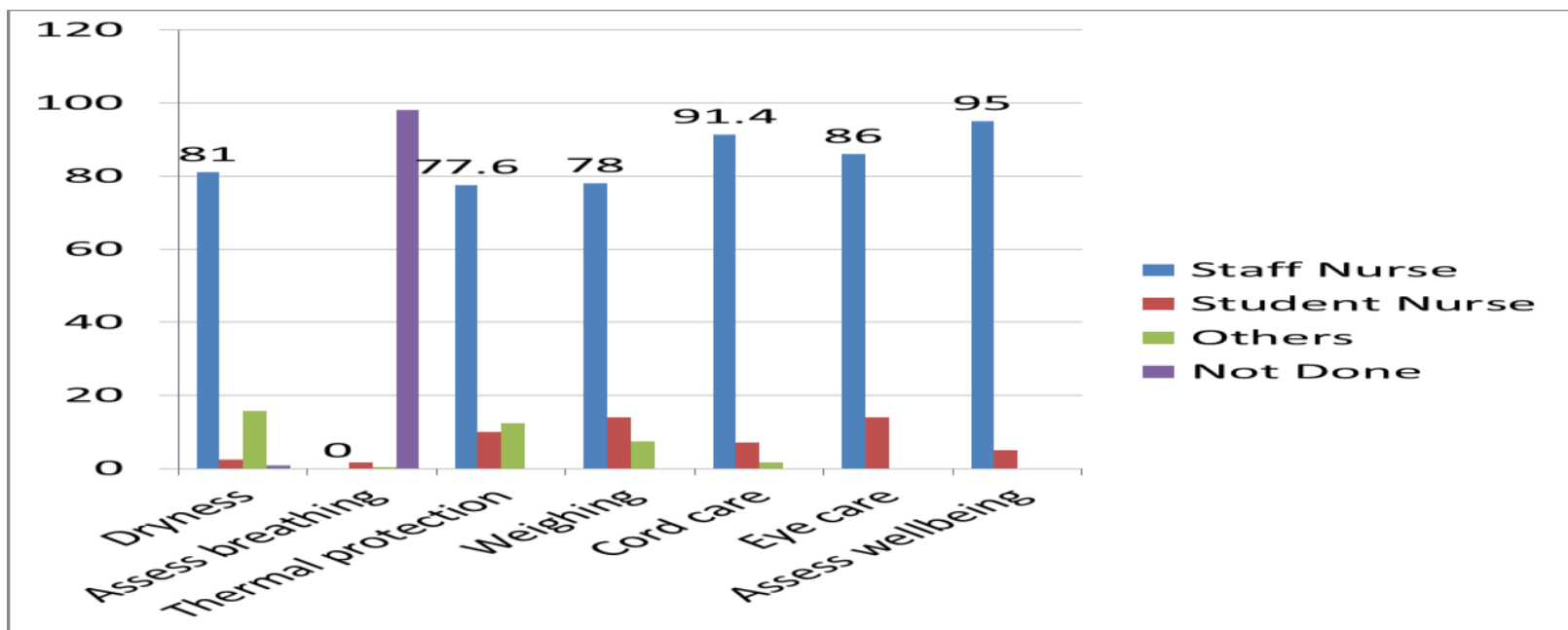

Figure (2): Distribution of the study subjects by immediate postpartum nursing care for the newborn $\&$ care providers.

Table (4 ): Distribution of the study subjects by hygienic advices \& care providers

\begin{tabular}{|l|c|c|c|c|c|c|c|c|}
\hline \multirow{2}{*}{\multicolumn{1}{|c}{ Items of care }} & \multicolumn{2}{c}{$\begin{array}{c}\text { Done by staff } \\
\text { nurse }\end{array}$} & \multicolumn{2}{c|}{$\begin{array}{c}\text { Done by student } \\
\text { nurse }\end{array}$} & \multicolumn{2}{c|}{ Done by others } & \multicolumn{2}{c|}{ Not done } \\
\cline { 2 - 11 } & No. & $\%$ & No. & $\%$ & No. & $\%$ & No. & $\%$ \\
\hline Wash hands before handling baby & 0 & 0.0 & 4 & 0.8 & 0 & 0.0 & 496 & 99.2 \\
\hline Wash hands before feeding baby & 0 & 0.0 & 7 & 1.4 & 0 & 0.0 & 493 & 98.6 \\
\hline Wash perineum daily & 0 & 0.0 & 50 & 10.0 & 0 & 0.0 & 450 & 90.0 \\
\hline Wash hands after fecal excretion & 0 & 0.0 & 10 & 2.0 & 0 & 0.0 & 490 & 98.0 \\
\hline Wash hands before preparing food & 0 & 0.0 & 8 & 1.6 & 0 & 0.0 & 492 & 98.4 \\
\hline Whange pads every 4-6 hours & 0 & 0.0 & 38 & 7.6 & 0 & 0.0 & 462 & 92.4 \\
\hline Wash the body daily & 0 & 0.0 & 49 & 9.8 & 0 & 0.0 & 451 & 90.2 \\
\hline
\end{tabular}

Others mean obstetrician or nurse's aids

Table (5): Distribution of the study subjects by breastfeeding advices $\&$ care providers.

\begin{tabular}{|l|c|c|c|c|c|c|c|c|c|}
\hline \multicolumn{1}{|c|}{ Items of care } & \multicolumn{2}{c|}{$\begin{array}{c}\text { Done by } \\
\text { staff nurse }\end{array}$} & \multicolumn{2}{c|}{$\begin{array}{c}\text { Done by } \\
\text { student nurse }\end{array}$} & \multicolumn{2}{c|}{$\begin{array}{c}\text { Done by } \\
\text { others }\end{array}$} & \multicolumn{2}{c|}{ Not done } \\
\cline { 2 - 10 } & No. & $\%$ & No. & $\%$ & No. & $\%$ & No. & $\%$ \\
\hline $\begin{array}{l}\text { Keep newborn in skin-to-skin contact with mother } \\
\text { soon after delivery. }\end{array}$ & 138 & 27.6 & 93 & 18.6 & 11 & 2.2 & 258 & 51.6 \\
\hline Initiate breastfeeding within 1/2 to 1 hour after birth. & 109 & 21.8 & 90 & 18.0 & 13 & 2.6 & 288 & 57.6 \\
\hline $\begin{array}{l}\text { Give baby the first milk (colostrums), which is } \\
\text { nutritious. }\end{array}$ & 11 & 2.2 & 95 & 19.0 & 93 & 18.6 & 301 & 60.2 \\
\hline $\begin{array}{l}\text { Counsel on exclusive breastfeeding. WHO } \\
\text { recommends that infants should be breastfed } \\
\text { exclusively from birth to at least 4 and if possible 6 } \\
\text { months of age }\end{array}$ & 0 & 0.0 & 88 & 17.6 & 3 & 0.6 & 409 & 81.8 \\
\hline $\begin{array}{l}\text { Emphasize that breastfeeding should be given as often } \\
\text { as the child desires, day and night, at least 8 times in } \\
\text { 24 hours. }\end{array}$ & 1 & 0.2 & 79 & 15.8 & 1 & 0.2 & 419 & 83.8 \\
\hline $\begin{array}{l}\text { Teach correct positioning and attachment for } \\
\text { breastfeeding. }\end{array}$ & 0 & 0.0 & 36 & 7.2 & 36 & 7.2 & 428 & 85.6 \\
\hline Advise the mother to drink plenty of fluids, eat more, & 0 & 0.0 & 95 & 19.0 & 76 & 15.2 & 329 & 65.8 \\
\hline
\end{tabular}




\begin{tabular}{|c|c|c|c|c|c|c|c|c|}
\hline \multirow[t]{2}{*}{ Items of care } & \multicolumn{2}{|c|}{\begin{tabular}{|c|} 
Done by \\
staff nurse
\end{tabular}} & \multicolumn{2}{|c|}{\begin{tabular}{|c|} 
Done by \\
student nurse
\end{tabular}} & \multicolumn{2}{|c|}{$\begin{array}{l}\text { Done by } \\
\text { others }\end{array}$} & \multicolumn{2}{|c|}{ Not done } \\
\hline & No. & $\%$ & No. & $\%$ & No. & $\%$ & No. & $\%$ \\
\hline \multicolumn{9}{|l|}{ eat healthy foods and rest while breastfeeding, } \\
\hline Discuss benefits for the mother & 0 & 0.0 & 96 & 19.2 & 0 & 0.0 & 404 & 80.8 \\
\hline $\begin{array}{l}\text { Postpartum bleeding can be reduced due to uterine } \\
\text { contractions caused by the baby's suckling. }\end{array}$ & 0 & 0.0 & 93 & 18.6 & 0 & 0.0 & 407 & 81.4 \\
\hline Breastfeeding can help delay a new pregnancy. & 0 & 0.0 & 95 & 19.0 & 0 & 0.0 & 405 & 81.0 \\
\hline Talk about benefits for the baby & 0 & 0.0 & 93 & 18.6 & 0 & 0.0 & 407 & 81.4 \\
\hline $\begin{array}{l}\text { Breast milk contains the water and the nutrients that a } \\
\text { baby's body needs and is easily digested by the baby. }\end{array}$ & 0 & 0.0 & 93 & 18.6 & 0 & 0.0 & 407 & 81.4 \\
\hline $\begin{array}{l}\text { Breast milk has unique antibodies that help protect the } \\
\text { baby against infections. }\end{array}$ & 0 & 0.0 & 97 & 19.4 & 0 & 0.0 & 403 & 80.6 \\
\hline
\end{tabular}

Others mean obstetrician or nurse's aids

Table (6):Distribution of the study subjects by nutritional advices and care providers.

\begin{tabular}{|c|c|c|c|c|c|c|c|c|}
\hline \multirow[t]{2}{*}{ Items of care } & \multicolumn{2}{|c|}{$\begin{array}{c}\text { Done by } \\
\text { staff nurse }\end{array}$} & \multicolumn{2}{|c|}{$\begin{array}{c}\text { Done by } \\
\text { student } \\
\text { nurse }\end{array}$} & \multicolumn{2}{|c|}{$\begin{array}{c}\text { Done by } \\
\text { others }\end{array}$} & \multicolumn{2}{|c|}{ Not done } \\
\hline & No. & $\%$ & No. & $\%$ & No. & $\%$ & No. & $\%$ \\
\hline $\begin{array}{l}\text { Women's food intake should be increased by } 10 \% \text { to } 20 \% \\
\text { during lactation. Advise the woman to eat a greater amount } \\
\text { and variety of healthy foods. Give examples of types of } \\
\text { food and the amount to eat }\end{array}$ & 0 & 0.0 & 85 & 17.0 & 0 & 0.0 & 415 & 83.0 \\
\hline $\begin{array}{l}\text { Determine if there are taboos about foods which are } \\
\text { nutritionally healthy. Advise the woman against all dietary } \\
\text { restrictions }\end{array}$ & 0 & 0.0 & 2 & 0.4 & 0 & 0.0 & 498 & 99.6 \\
\hline $\begin{array}{l}\text { Advise and counsel on the effects of iodine deficiency to } \\
\text { the fetus (e.g., brain damage) and in childhood (e.g., mental } \\
\text { retardation, neurological disorders, cretinism) }\end{array}$ & 0 & 0.0 & 4 & 0.8 & 0 & 0.0 & 496 & 99.2 \\
\hline $\begin{array}{l}\text { Advise and counsel on prevention of vitamin A deficiency- } \\
\text { effects of deficiency (e.g., childhood blindness) and types } \\
\text { of food to take to prevent deficiency }\end{array}$ & 0 & 0.0 & 5 & 1.0 & 0 & 0.0 & 495 & 99.0 \\
\hline $\begin{array}{l}\text { Explain that Vitamin A will help her to recover better and } \\
\text { that the baby will receive the vitamin through her breast } \\
\text { milk }\end{array}$ & 0 & 0.0 & 5 & 1.0 & 0 & 0.0 & 495 & 99.0 \\
\hline $\begin{array}{l}\text { Anemia aggravates the effects of maternal blood loss and is } \\
\text { thereby a major contributor to maternal mortality in the } \\
\text { postpartum period }\end{array}$ & 0 & 0.0 & 55 & 11.0 & 0 & 0.0 & 445 & 89.0 \\
\hline $\begin{array}{l}\text { Encourage the consumption of foods rich in iron (dark } \\
\text { green leafy vegetables) and foods which enhance iron } \\
\text { absorption (fruits and vegetables rich in vitamin C) }\end{array}$ & 0 & 0.0 & 84 & 16.8 & 0 & 0.0 & 416 & 83.2 \\
\hline Birth spacing and family planning & 0 & 0.0 & 96 & 19.2 & 0 & 0.0 & 404 & 80.8 \\
\hline Immunization of mother and newborn & 0 & 0.0 & 87 & 17.4 & 0 & 0.0 & 413 & 82.6 \\
\hline
\end{tabular}

The age of the study subjects Table (1) : ranged between 19-45 yaers with the mean of $27.83 \pm 4.85$ years. Nearly half of them $(45.2 \%)$ with secondary education.Vast majority of the subjects $(96.2 \%)$ were house wives, and more than three quarters of them (76.2\%)were from rural areas.

As regads obstertrical history Table (2) : more than two-thirds of the subjects $(68.8 \%)$ were multiparae.
The episiotomy were done to all primiparae (18.2\%) included in this study, Figure (1):Concerning immediate post-partum care provided to parturients, Table(3) : nearly half of the study subjects (43\%) assessed by the nurse for uterine contractions \& fundal height, while encouraged empty bladder not done for all parturients. Check for completelness of the the placenta done by others (obstetrician or 
nurse's aids) in about $69.4 \%$ of the study subjects, also encourage parturients to eat $\&$ drink done for about $76.6 \%$ of the study subjects by them.

Assessed general well-being of the newborn

Figure (2) : done by nurses for $95 \%$ of subjects, while monitoring baby for breathing not done for $98 \%$ of subjects.

Hygienic advices Table (4) : not done by nurses for all subjects.

Breast feeding advices Table (5) : keep skin to skin contacts and initiation of breast feeding early were discussed by the nurse in $27.6 \% \& 21.8 \%$ of subjects respectively.

Nutritional advices Table (6) : the nurse not provide any nutritional advices with the study subjects during the period of the study.

\section{Discussion}

An audit is an objective, systematic \& critical analysis of medical care.(Wagaarachchi, Graham, 2001). Routine clinical audits can easly be implemented in obstertric settings, (Dupont, 2009). Nursing audit measures the quality of nursing care actually given to patients, (Jairus, \& Walia, 2011). This study aimed at identify the gap between the current \& the ideal immediate normal postpartum nursing care at Woman's Health University Hospital, Assiut.

As regards assessed general well-being of the newborn, the results of the present study revealed that the percentage of 95 of the study subjects received their care by the staff nurse. Keep the newborn in skin to skin contact with mother soon after delivery done by staff nurse for $27.6 \%$ of the study subjects. These findings were in agreement with the (study done in 2012) to investigate the clinical practice guiselines on intrapartum \& immediate post-partum care. The study recomended skin to skin contact between mother \& baby at birth \& early initiation of breast feeding which considered to be part \& parcel of good practice in all birthing facilities (A collaboration of the department of health and Philippine obstetrical \& gynecological society, 2012).

Findings of the present study showed that the mean age of women was $27.83 \pm 4.85$ years. Also showed a gab between the current and ideal care (recommended by WHO), provided immediately to post-partum women at woman's health university hospital, Assiut. These results were in agreement with the study done by (Kongnyuy, et al., 2008), a hospital-based study in Malawi, who stated that the mean age of women was 25 years, also when the first audit was performed in their study, wide gaps were identified between current practices \& standards.
Other study conducted in Dar assalam, Tanzania (Kidanto, 2009), to improve quality of perinatal care, identified inadequate maternal \& fetal monitoring during labor. Also identified suboptimal care in about $80 \%$ of audited cases. Other study done by Navkiran, et al., (2014) who work on skill development of nurses in managing the fourth stage of labour they found that, in spite of the fact that the fourth stage is such an important stage to be managed, the staff nurses were not following the steps for managing the fourth stage of labour properly.

As regards immediate postpartum care provided to parturient, findings of the present study showed that the only item of care provided by nurses (among those items recommended by WHO \& included in the audit chart), was the assessment of uterine contractions (among $43 \%$ of subjects). Other items of care for example check for completelness of the placenta done by others than nurse (obstetrician or nurse's aids) in about $69.4 \%$ of subject. Encourage parturient to eat and drink done by obstetrician or nurse's aids among $76.6 \%$ of the study subjects. On the other hand there were items of care not done by any person for example, encourage mother to empty her bladder, advice on time of next postpartum visit and nutritional advices. . These finding are in agreement with the study done at University hospital in ShebinEl-Kom Menoufiya by Abdel Fattah \& Zein EIDein (2012), they stated that much still needs to be done to improve the quality of maternal $\&$ newborn care.

These findings could be explained by many reasons including:- Shortage in number of nurses, there were only two working nurses during each shift (morning, afternoon, neight). Poor of documentation system.Working nurses were disadvantaged in continuing educational programs which increase their knowledge \& improve their skills. Lack of continuous supervision and annual evaluation for their performance. Absence of job specification plus shortage in staffing lead to overlapping in providing items of care and negligance other items of care. Early discharge after delivery may be a cause make inadequate time to provide the instructions and advices necessary for parturients. Lastly and not least involving the working nurses in administrative duties other than their duties as a health care providers which make them overloaded.

\section{Conclusion}

A gaps were identified between current and ideal immediate normal postpartum nursing care. It is concluded that all items of immediate post-partum care recommended dy WHO except check for 
uterine contractions not provided by the staff nurses . Hygienic \& nutritional advices not provided to all of the study subjects by staff nurses. Immediate newborn care was the most items of care provided by the staff nurse.

\section{Recommendations}

On the light of findings of the present study the following recommendations was developed

1-Re-audit to improve immediate post-partum care provided.

2-Polices \& regulations recommended nurse/patients ratio to improve the quality of health care.

3-Importance of participation of the nurses in continuous educational programs.

\section{References}

1. A Collaboration of the Department of Health \& the Philippine Obstetrical and Gynecological Society, (2012): Clinical Practical Guidelines on Intrapartum \& Immediate Post-partun care.

2. Abd El Fattah N., and Zein El Dein N., (2012): Assessment of Quality of Nursing Care Provided Immediately After Birth At University Hospital. Life Sci J.;9(4):2115-2126] (ISSN: 1097-8135). http://www.lifesciencesite.com. 316

3. Bethany Derricott, B., M., R., (2010): Wild Iris Medical Education, Inc. Is an Approved Provider of Continuing Nursing Education by the American Nurses Credente.

4. Dupont C., Touzet S., Colin C., DeneuxTharaux C., Rabilloud M., \& Clement H., (2009): Incidence and management of postpartum haemorrhage following the dissemination ofguidelines in a network of 16 maternity units in France. Int J Obstet Anesth . 18 : (4 ) Pp. 320 - 7

5. Graham W., Wagaarachchi P., \& Penney G., (2012): Criteria for Clinical Audit of the Quality of Hospital-Based Obstetric Care in Developing Countries. Bull World Health Organization, 78: Pp 614-20.

6. Jairus R., \& Walia I., (2011): Nursing Audit. The Nursing Journal of India, June, vol c11 No.6.

7. John W., \& Sons, l., (2007): The Cochran Collaboration, Prophylaxis for Cesarean Section, Review(2).

8. Kidanto H., (2009): Improving quality of perinatal care through clinical audit: Epidemiology \& Global Health. Department of Public Health \& Clinical Medicine. Umea University ,SE- 90187.
9. Kittson H., Mogren I., \& Massawe S., (2012): Criteria-based audit on management of eclampsia patients at a tertiary hospital in Dar el Salaam, Tanzania. BMC Pregnancy Childbirth ;9:13.

10. Kongyuy E., Malava G., Broek N., \& Van den,(2008): Using criteria-Based Audit to Improve the Management of Post-partum Hemorrhage in Resources Limited countries: Acase Study of Malawy. Maternal \& Child Health Journal, DOI 10. 1007/ s10995-0080408-3

11. Moldenhauer J., (2013): Postpartum depression. Merck manual for health care professionals. Retrieved from http://www.merckmanuals.com

12. Navkiran Kaur, Sukhjit Kaur, P., Saha, (2014): Skill development of Nurses in Managing the 4 th stage of labor. Nursing \& midwifery reseach journal, vol-10, no.1, January, Pp 16-29.

13. NHS Executive, (2010): Promoting clinical effectiveness. A Framework for Action in and Through the NHS. London: NHS Executive.

14. Ricci \& Kyle, (2009): Postpartum Adaption, Maternity and Pediatric Nursing Care, chapter 15, pp.430-439.

15. Swell B., (2007): The Right kind of Help. RCM Midwives 10(2):85.the fourth stage of Labour. Nursing and Midwifery Research Journal, Vol10, No.1, January , pp 16-29

16. Wagaarachchi P., Graham W., Penney G., McCaw-Binns A., Yeboah Antwi K., \& Hall M., (2001): "Holding up a mirror: changing obstetric practice through criterion based clinical audit in developing countries." Int J Gynec Obstet.74: Pp 119-130.

17. WHO (World Health Organization), (2003): Pregnancy, Childbirth, Postpartum and Newborn Care: A guide for essential practice. www.who.int/reproductive health/publications/pcpnc/

18. World Health Organization, (2006): Integrated Management of Pregnancy and Childbirth Services (IMPAC). Geneva: WHO (retrieved 20 April 2007) http://www.euro.who.int/pregnancy/esscare/2005 1103_3?language=german.

19. World Health Organization, (2010): WHO Technical Consultion on Postpartum and Postnatal Care, Department of Making Pregnancy Safer.

20. Wray S., Jones K., Kupittayanant S., et al., (2008): Calcium Signaling and Uterine Contractility. J Soc Gynecologic Investing. 10(5):252- 64 . 
